\title{
THE CURRENT STATUS OF ABET ACCREDITATION OF INFORMATION SYSTEMS PROGRAMS
}

\author{
Ronald J. MacKinnon, Georgia Southern University, rmackinn@georgiasouthern.edu \\ Kevin L. Elder, Georgia Southern University, kelder@georgiasouthern.edu \\ John N. Dyer, Georgia Southern University, jdyer@georgiasouthern.edu
}

\begin{abstract}
As of March 2012 there were 35 Information Systems (IS) programs at 34 universities accredited by the Accreditation Board for Engineering and Technology (ABET). This paper investigates these ABET accredited IS programs to see what these programs have in common and how do they differ from other IS programs. The data was collected by visiting the web pages of the selected IS programs. This paper includes a study of the required IS courses, elective IS courses, required programming courses, required business courses, the title of the IS program (IS/MIS/CIS), the department and college where the IS program was located and the year of ABET accreditation. It is interesting to notice that after 21 years of IS accreditation, only one of the ABET accredited IS degrees is a BBA degrees. This study points out several significant differences between the ABET accredited IS programs and the typical BBA IS programs at the sample universities. The growth of ABET accreditation has been slow, 35 programs over 10 years. ABET accreditation of engineering and computer science is the norm but ABET accreditation of IS programs is not the norm. It is interesting to note that none of the top rated IS programs in US News \& World Report are ABET accredited.
\end{abstract}

Keywords: ABET, Accreditation, Information Systems

\section{INTRODUCTION}

The Accreditation Board for Engineering and Technology (ABET) has been accrediting engineering programs since 1936, and almost every engineering program in the US is ABET accredited. In 1985 ABET helped to establish the Computer Science Accreditation Board (CSAB) and ABET has also become the standard for CS accreditation. 259 computer science programs have been ABET accredited by ABET by October 1, 2011 and ABET accredits a total of over 3,000 applied science, computing, engineering, and technology programs worldwide.

The Association to Advance Collegiate Schools of Business (AACSB) is the professional accrediting agency for business and accounting programs and by December 2011 AACSB has accredited 643 business and accounting programs. Most Information Systems (IS) programs are in schools of business and are included in the overall accreditation of the school of business. It was a surprise to many people that ABET started to accredit IS programs in 2000. Does AIS have a position on accreditation? Topi (2011) states "Since Spring 2008, there has been an active debate within AIS regarding the role the Association should have in Information Systems accreditation."

IS accreditation by ABET has been a topic of interest to IS professionals. In IACIS there have been articles ( Kohun and Wood, 2004; Jones, 2004; MacKinnon and Butler, 2005, Kohun, DeLorenza \& Rodi 2011), ISECON (Hilton and Stone, 2003; Hilton, Johnson and Kasper, 2004) and JISE (Kohum \& Wood, 2003; Challa, Kasper, and Redmond 2005).

Hilton's study of IS programs Hilton (2007), found that $92 \%$ of the IS programs that he surveyed had their business school accredited by AACSB and less that $1 \%$ of them were accredited by ABET (Hilton and Lo, 2007).

This paper summarizes the results of 2005 and 2008 ABET accreditation of IS programs and investigates the IS programs accredited since 2008. 


\section{Issues in Information Systems}

Volume 13, Issue 1, pp. 151-159, 2012

\section{METHODOLOGY AND DATA ANALYSIS}

In 2005 the ISWorld web pages listed 251 IS programs at US universities. A sample of 20 of these universities was chosen by selecting every $12^{\text {th }}$ university. These IS programs were compared to ABET accredited IS programs.

The analysis of the IS programs was done by examining the web pages of the universities. It is noted that some pages are up to date and some other universities take a while to update the curriculum changes on their web pages.

\section{DEPARTMENT, TITLE AND COLLEGE}

The results of the MacKinnon and Butler study (2005) are listed in Table 1.

\begin{tabular}{|l|l|l|l|l|l|}
\hline$\#$ & University & Department & IS Course & Degree & College \\
\hline & & & Title & & \\
\hline 1 & Drexel U & None & IS & BS & IS \& Technology \\
\hline 2 & Illinois State U & School of IT & MIS & BIS & School of IT \\
\hline 3 & Kennesaw State U & CS \& IS & IS & BS & College of Science \& Math \\
\hline 4 & U of Nebraska, Omaha & IS \& Quant & MIS & BS & College of IS \& Technology \\
\hline 5 & NJ Institute of Tech & IS & IS & BS & College of Computing Sciences \\
\hline 6 & U of North Florida & C \& IS Sciences & IS & BS & School of Computing \\
\hline 7 & Pace U & None & IS & BS & School of CS \& IS \\
\hline 8 & Robert Morris U & CIS & ISM & BS & School of Comm \& IS \\
\hline 9 & U of South Alabama & C \& IS & IS & BS & School of Computer \& IS \\
\hline 10 & Virginia Commonwealth U & IS & IS & BS & School of Business \\
\hline
\end{tabular}

Table 1. ABET Accredited IS Programs in 2005

The title of the IS courses and the department they are located in are not surprising but it is surprising that of the first 10 IS programs approved by ABET only one program was located in a school of business.

By 2008 there were 23 IS programs accredited by ABET, as shown in Table 2 ( MacKinnon and Han, 2008). There was a major change with the 13 additional accredited IS programs. Now ten of twenty three IS programs were located in a school or college of business. There is a wide variety in the names of the departments are housed. For course titles, 8 universities use IS, 5 universities use MIS and 5 universities use CIS and there are 5 other names.

By 2012 there were an additional 13 IS programs accredited by ABET. Only 4 of these programs were in schools/colleges of business as shown in Table 3 .

The number of IS programs accredited by year is shown in Table 4. Over the past 10 years 35 programs have been accredited. That is an average of 3.5 programs but only 1 program was accredited in 2010.

The summary of the 35 IS programs accredited in 2012 are listed in table 5

To put these results into perspective, Table 6 lists 20 typical IS programs selected from ISWorld. There are two items that stand out. Most IS programs are in schools/colleges of business and are BBA degrees. The ABET accredited IS programs have 33 BS degrees and only one BBA degree. This was true in the 2005 study and the 2008 study and it is still true in 2012 . 


\section{Issues in Information Systems}

Volume 13, Issue 1, pp. 151-159, 2012

\begin{tabular}{|l|l|l|l|}
\hline University & Department & \multicolumn{1}{|c|}{ TS } & College \\
\hline Drexel U & None & IS & IS \& Technology \\
\hline Gannon & Computer \& Info Sciences & MIS & College of Hum, Bus \& Educ \\
\hline Houston-Clear Lake & Comp \& Math Division & CIS & School of Sci \& Engineering \\
\hline Illinois State U & School of IT & MIS & School of IT \\
\hline Jacksonville SU & Math, Computing \& IS & CIS & College of Arts \& Science \\
\hline James Madison & CIS \& Mgmt Sci & CIS & College of Business \\
\hline Kennesaw State U & CS \& IS & IS & Science \& Math \\
\hline Lock Haven & Bus, CS \& IT & CIS & College of Arts \& Science \\
\hline Maine & SIS \& Engineering & ISE & Engineering \\
\hline Metropolitan S College & CIS & MIS & School of Business \\
\hline U of Nebraska, Omaha & IS \& Quant & MIS & IS \& Technology \\
\hline NJ Institute of Tech & IS & IS & Computing Sciences \\
\hline U of North Florida & C \& IS Sciences & IS & Engin \& Construction \\
\hline Pace U & None & IS & School of CS \& IS \\
\hline Quinnipiac U & Info Sys Mgmt & ISM & School of Business \\
\hline Robert Morris U & CIS & ISM & School of Comm \& IS \\
\hline U Scranton & Comp Sciences & CIS & School of Management \\
\hline Slippery Rock & Computer Science & IS & Bus, Info \& Social Sci \\
\hline U of South Alabama & C \& IS & IS & School of Computer \& IS \\
\hline U South Carolina & Computer Sci \& Engineer & BIS & College of Engin \& Comput \\
\hline Utah S U & Computer Science & CS & College of Science \\
\hline Virginia Commonwealth U & IS & IS & School of Business \\
\hline Wright SU & IS \& Oper Mgmt & MIS & College of Business \\
\hline
\end{tabular}

Table 2. ABET Accredited IS Programs in 2008

\begin{tabular}{|l|l|l|l|l|l|}
\hline$\#$ & University & Department & IS Course & Deg & College \\
\hline & &. & Title. & &. \\
\hline 1 & Arkansas Tech U? & C \& Info Sc & IS & BS & Applied Sciences \\
\hline 2 & California SU, Chico & Acct \& MIS & MIS & BS & Business \\
\hline 3 & California U of Penn & Math, CS \& IS & CIS & BS & Science \& Tech \\
\hline 4 & Fitchburg S College & Computer Science & CIS & BS & None \\
\hline 5 & Florida Memorial U & CS \& Math & CIS & BS & School of Arts \& Sc \\
\hline 6 & Grand Valley SU & School of Comp \& IS & IS & BA & Engineering \& Comp \\
\hline 7 & Radford U & Info Tech & IS & BS & Science \& Technology \\
\hline 8 & Regis U & None & CIS & BS & School of C \& IS \\
\hline 9 & Rowan U & None & MIS. & BS & Business. \\
\hline 10 & Southern Utah U & CSIS, S Comp \&Tech & IS & BS & Science \& Engineering \\
\hline 11 & U of Tampa & Info \& Tech Mgmt & MIS & BS & Business \\
\hline 12 & U Arkansas, Little Rock & Info Sc & IS & BS & Engin \& IT \\
\hline 13 & U of North Alabama & CS \& IS & CIS & BBA & Business \\
\hline 14 & Utah Valley U & IS \& Technology & INFO & BS & Technology \& Computing \\
\hline
\end{tabular}

Table 3. ABET Accredited IS Programs 2008-2012 


\section{Issues in Information Systems}

Volume 13, Issue 1, pp. 151-159, 2012

\begin{tabular}{|c|c|c|c|}
\hline $\begin{array}{c}\text { Year Program Was } \\
\text { Accredited }\end{array}$ & $\begin{array}{c}\text { No of IS Programs } \\
\text { Accredited }\end{array}$ & $\begin{array}{c}\text { Year Program Was } \\
\text { Accredited }\end{array}$ & $\begin{array}{c}\text { No of IS Programs } \\
\text { Accredited }\end{array}$ \\
\hline 2000 & 1 & 2006 & 4 \\
\hline 2001 & 6 & 2007 & 2 \\
\hline 2002 & 3 & 2008 & 3 \\
\hline 2003 & 3 & 2009 & 3 \\
\hline 2004 & 4 & 2010 & 1 \\
\hline 2005 & 3 & Total 2000-2010 & 35 \\
\hline
\end{tabular}

Table 4 The Number of IS Programs Accredited by Year

\begin{tabular}{|c|c|c|c|c|c|c|}
\hline \# & University & ABET & Department & IS & Deg & College \\
\hline & & Acred & & & & \\
\hline & & Year & & Title & & \\
\hline 1 & Arkansas Tech & 2006 & C \& Info Science & IS & BS & Applied Science \\
\hline 2 & California SU, Chico & 2008 & Acct \& MIS & MIS & $B S$ & Business \\
\hline 3 & California U of Penn & 2008 & Math, CS \& IS & CIS & BS & Science \& Tech \\
\hline 4 & Drexel U & 2001 & None & IS & BS & IS \& Technology \\
\hline 5 & Fitchburg State College & 2006 & Computer Science & CIS & BS & None \\
\hline 6 & Florida Memorial U & 2008 & CS \& Math & CIS & BS & School of Arts \& Science \\
\hline 7 & Gannon & 2004 & Computer \& Info Sciences & MIS & BS & Hum, Bus \& Education \\
\hline 8 & Grand Valley SU & 2007 & School of Comp \& IS & IS & BA & Engineering \& Comp \\
\hline 9 & Illinois State U & 2001 & School of IT & MIS & $\mathrm{BiS}$ & School of IT \\
\hline 10 & Jacksonville SU & 2003 & Math, Computing \& IS & CIS & BS & Arts \& Science \\
\hline 11 & James Madison & 2003 & CIS \& Mgmt Sci & CIS & $B S$ & Business \\
\hline 12 & Kennesaw State U & 2002 & CS \& IS & IS & BS & Science \& Math \\
\hline 13 & Metropolitan S College & 2005 & CIS & MIS & $B S$ & School of Business \\
\hline 14 & NJ Institute of Tech & 2002 & IS & IS & BS & Computing Sciences \\
\hline 15 & Pace U & 2000 & None & IS & BS & School of CS \& IS \\
\hline 16 & Quinnipiac U & 2005 & Info Sys Mgmt & ISM & $B S$ & School of Business \\
\hline 17 & Radford U & 2008 & Info Tech & IS & BS & Science \& Technology \\
\hline 18 & Regis U & 2010 & None & CIS & BS & School of C \& IS \\
\hline 19 & Robert Morris U & 2001 & CIS & ISM & BS & School of Comm \& IS \\
\hline 20 & Rowan U & 2006 & None & MIS & $\mathrm{BS}$ & Business \\
\hline 21 & Slippery Rock & 2003 & Computer Science & IS & $\mathrm{BS}$ & Bus, Info \& Social Sci \\
\hline 22 & Southern Utah U & 2009 & CSIS, Sch Comp \& Tech & IS & BS & Science \& Engineering \\
\hline 23 & $\mathrm{U}$ of Tampa & 2009 & Info \& Tech Mgmt & MIS & BS & Business \\
\hline 24 & U Arkansas, Little Rock & 2006 & Info Sc & IS & $\mathrm{BS}$ & Engineering \& IT \\
\hline 25 & U Houston, C of Tech & 2009 & Info \& Logistics Technology & CIS & BS & Technology \\
\hline 26 & U Houston-Clear Lake & 2004 & Comp \& Math Division & CIS & BS & Sch of Science \& Engin \\
\hline 27 & U Nebraska, Omaha & 2002 & IS \& Quant & MIS & BS & IS \& Technology \\
\hline 28 & U North Alabama & 2006 & CS \& IS & CIS & $B B A$ & Business \\
\hline 29 & U North Florida & 2001 & C \& IS Sciences & IS & BS & School of Computing \\
\hline 30 & U of South Alabama & 2001 & C \& IS & IS & BS & School of Computer \& IS \\
\hline 31 & U South Carolina & 2004 & Computer Sci \& Engineering & BIS & $\mathrm{BS}$ & Engin \& Computing \\
\hline 32 & Utah S U & 2005 & Computer Science & $\mathrm{CS}$ & BS & Science \\
\hline 33 & Utah Valley U & 2007 & IS \& Tech & IS & BS & Technology \& Computing \\
\hline 34 & Virginia Commonwealth & 2001 & IS & IS & BS & School of Business \\
\hline 35 & Wright SU & 2004 & IS \& Oper Mgmt & MIS & BS & College of Business \\
\hline
\end{tabular}

Table 5. ABET Accredited IS Programs in 2012 


\section{Issues in Information Systems}

Volume 13, Issue 1, pp. 151-159, 2012

\begin{tabular}{|l|l|l|l|}
\hline University & Department & IS Title & College \\
\hline Baylor U & IS & ISY & COB \\
\hline Bowling Green SU & A \& MIS & MIS & CBA \\
\hline Central Connecticut SU & MIS & MIS & SOB \\
\hline Colorado State U & CIS & BD & COB \\
\hline Eastern Michigan U & CIS & ISM & COB \\
\hline Florida Gulf Coast U & CIS & ISM & COB \\
\hline Georgia College \& SU & IS,C \& M & CBIS & COB \\
\hline James Madison & IT \& MS & CIS & COB \\
\hline Louisiana State U & IS \& DS & ISDS & COB \\
\hline Middle Tennessee SU & CIS & CIS & COB \\
\hline Northwest Missouri SU & CS/IS & MIS & COB \\
\hline Oklahoma State U & MS \& IS & MIS & COB \\
\hline San Diego State U & IDS & IDS & COB \\
\hline Temple U & MIS & MIS & SOB \\
\hline U of Alabama, Huntsville & None & MIS & CAS \\
\hline U of Central Florida & MIS & MIS & COB \\
\hline U of Maryland, BC & IS & IS & None \\
\hline U New Mexico & M,IS \& DS & MGT & SOM \\
\hline U of South Florida & IS DS & MIS & COB \\
\hline Western Carolina U & BCIS \&Econ & CIS & COB \\
\hline
\end{tabular}

Table 6. Random Sample of IS Departments in 2005

\section{IS DEGREE NAME AND BUSINESS CREDITS REQUIRED}

Table 6 (MacKinnon, Butler, 2005) shows the college and the department and the IS course title of IS programs that were ABET accredited in 2005. Nine of the degrees were BS degrees and one degree was a Bachelor of Information Systems (BIS) degree.

\begin{tabular}{|l|c|c|c|c|c|}
\hline $\begin{array}{l}\text { University } \\
\text { Names }\end{array}$ & $\begin{array}{l}\text { ABET IS } \\
\text { Accredited } \\
\text { Year }\end{array}$ & $\begin{array}{l}\text { ABET IS } \\
\text { Degree } \\
\text { Name }\end{array}$ & $\begin{array}{l}\text { Business } \\
\text { Credits } \\
\text { Required }\end{array}$ & $\begin{array}{l}\text { Existence } \\
\text { of } \\
\text { BBA IS }\end{array}$ & $\begin{array}{l}\text { Existence } \\
\text { of } \\
\text { CS Degree }\end{array}$ \\
\hline Drexel U & 2001 & BS & 27 & Y & Y \\
\hline Illinois State U & 2001 & BIS & 22 & BIS & Y \\
\hline Kennesaw State U & 2002 & BS & 27 & N & Y \\
\hline U of Nebraska, Omaha & 2002 & BS & 20 & N & Y \\
\hline NJ Institute of Tech & 2002 & BS & 15 & N & Y \\
\hline U of North Florida & 2001 & BS & 12 & N & Y \\
\hline Pace U & 2000 & BS & $6+17$ opt & Y & Y \\
\hline Robert Morris U & 2001 & BS & 15 & N & SE \\
\hline U of South Alabama & 2001 & BS & 24 & N & Y \\
\hline Virginia Commonwealth U & 2001 & BS & 39 & N & Y \\
\hline Average & & & $20.7-21.8$ & & \\
\hline
\end{tabular}

Table 7. ABET IS Accredited Characteristics in 2005 


\section{Issues in Information Systems}

Volume 13, Issue 1, pp. 151-159, 2012

\begin{tabular}{|c|c|c|c|c|c|c|c|}
\hline University & $\begin{array}{c}\text { Year } \\
\text { ABET } \\
\text { Accred }\end{array}$ & $\begin{array}{c}\text { ABET } \\
\text { IS } \\
\text { Name }\end{array}$ & $\begin{array}{c}\text { Business } \\
\text { Credits } \\
\text { Required }\end{array}$ & $\begin{array}{c}\text { Existence } \\
\text { of } \\
\text { CS }\end{array}$ & $\begin{array}{c}\text { Existence } \\
\text { of } \\
\text { IT }\end{array}$ & $\begin{array}{c}\text { Existence } \\
\text { of } \\
\text { BBA IS }\end{array}$ & $\begin{array}{c}\text { Bus } \\
\text { AACSB } \\
\text { Accred }\end{array}$ \\
\hline Drexel U & 2001 & BS & 27 & Y & Y & Y & Y \\
\hline Gannon & 2004 & BS & 33 & Y & N & N & N \\
\hline Houston-Clear Lake & 2004 & BS & 12 & Y & N & BS CIS & Y \\
\hline Illinois State & 2001 & BIS & 22 & Y & N & BIS & Y \\
\hline Jacksonville S & 2003 & BS & 21 & Y & N & Mgmt/IM & Y \\
\hline James Madison & 2003 & BBA & $40-45$ & Y & N & Y & Y \\
\hline Kennesaw SU & 2002 & BS & 27 & Y & Y & N & Y \\
\hline Lock Haven & 2005 & BS & 21 & Y & N & N & N \\
\hline Maine & 2007 & BS & 15 & Y & N & N & Y \\
\hline Metropolitan SC & 2005 & BS & 30 & Y & N & N & N \\
\hline Nebraska,Omaha & 2002 & BS & 20 & Y & PhD & N & Y \\
\hline NJ Inst of Tech & 2002 & BS & 15 & Y & Y & N & Y \\
\hline North Florida & 2001 & BS & 12 & Y & N & N & Y \\
\hline Pace U & 2000 & BS & $6+17$ opt & Y & Y & Y & Y \\
\hline Quinnipiac U & 2005 & BS & 40 & Y & N & N & Y \\
\hline Robert Morris U & 2001 & BS & 15 & SE & N & N & N \\
\hline U Scranton & 2005 & BS & 18 & Y & N & N & Y \\
\hline Slippery Rock & 2003 & BS & 18 & Y & Y & N & N \\
\hline South Alabama & 2001 & BS & 24 & Y & Y & N & Y \\
\hline South Carolina & 2006 & BS & 60 & Y & N & N & Y \\
\hline Utah SU & 2005 & BS & 12 & Y & N & BA & Y \\
\hline Virginia Commonwealth & 2001 & BS & 39 & Y & Y & N & Y \\
\hline Wright SU & 2004 & BSB & 39 & Y & N & N & Y \\
\hline Average & & & $\mathbf{2 4 . 6 - 2 5 . 3}$ & & & & \\
\hline
\end{tabular}

Table 8. ABET IS Accredited Characteristics in 2008

\begin{tabular}{|l|l|c|c|c|c|c|c|c|}
\hline University & $\begin{array}{l}\text { Year } \\
\text { ABET } \\
\text { Accred }\end{array}$ & $\begin{array}{l}\text { ABET IS } \\
\text { Degree }\end{array}$ & $\begin{array}{l}\text { Business } \\
\text { Credits } \\
\text { Required }\end{array}$ & $\begin{array}{c}\text { Exist } \\
\text { of } \\
\text { CS }\end{array}$ & $\begin{array}{c}\text { Exist } \\
\text { of } \\
\text { IT }\end{array}$ & $\begin{array}{c}\text { Exist } \\
\text { Of } \\
\text { Engin }\end{array}$ & $\begin{array}{c}\text { Exist } \\
\text { of } \\
\text { BBA IS }\end{array}$ & $\begin{array}{c}\text { Bus } \\
\text { AACSB } \\
\text { Accred }\end{array}$ \\
\hline Arkansas Tech U & 2006 & BS & 15 & Y & Y & Y & N & Y \\
\hline California SU, Chico & 2008 & BS & 24 & Y & N & Y & Y & Y \\
\hline California U of Penn & 2008 & BS & 15 & Y & N & Y & N & N \\
\hline Fitchburg SU & 2006 & BS & 12 & Y & N & N & N & N \\
\hline Florida Memorial U & 2008 & BS & 15 & Y & N & N & N & N \\
\hline Grand Valley SU & 2007 & BS & 24 & Y & N & Y & BA & Y \\
\hline Radford U & 2008 & BS & 24 & Y & N & N & N & Y \\
\hline Regis U & 2010 & BS & 9 & Y & N & Y & N & N \\
\hline Rowan U & 2006 & BS & 24 & Y & N & Y & N & Y \\
\hline Southern Utah U & 2009 & BS & 18 & Y & N & Y & N & Y \\
\hline U of Tampa & 2009 & BS & 36 & N & N & N & N & Y \\
\hline U of Arkansas, Little Rock & 2006 & BS & 15 & Y & N & Y & N & Y \\
\hline U of North Alabama & 2006 & BBA & 36 & Y & N & N & N & Y \\
\hline Utah Valley U & 2007 & BS & 24 & Y & Y & N & N & Y \\
\hline Average & & & 20.8 & & & & & \\
\hline
\end{tabular}

Table 9. ABET IS Accredited Characteristics 2006-2012 


\section{Issues in Information Systems}

Volume 13, Issue 1, pp. 151-159, 2012

\begin{tabular}{|l|l|c|c|c|}
\hline $\begin{array}{l}\text { University } \\
\text { Names }\end{array}$ & $\begin{array}{c}\text { ABET } \\
\text { IS } \\
\text { Name }\end{array}$ & $\begin{array}{c}\text { Business } \\
\text { Credits } \\
\text { Required }\end{array}$ & $\begin{array}{c}\text { Existence } \\
\text { of } \\
\text { CS }\end{array}$ & $\begin{array}{c}\text { AACSB } \\
\text { IS } \\
\text { Accredited }\end{array}$ \\
\hline Baylor U & BBA & 54 & Y & Y \\
\hline Bowling Green SU & BS & 57 & Y & Y \\
\hline Central Connecticut SU & BBA & 27 & Y & N \\
\hline Colorado State U & BBA & 33 & Y & Y \\
\hline Eastern Michigan U & BBA & 36 & Y & Y \\
\hline Florida Gulf Coast U & BBA & 30 & Y & Y \\
\hline Georgia College \& SU & BBA & 18 & Y & Y \\
\hline James Madison & BBA & 39 & Y & Y \\
\hline Louisiana State U & BBA & 36 & Y & Y \\
\hline Middle Tennessee SU & BBA & 45 & Y & Y \\
\hline Northwest Missouri SU & BBA & 33 & Y & N \\
\hline Oklahoma State U & BBA & 36 & Y & Y \\
\hline San Diego State U & BBA & 33 & Y & Y \\
\hline Temple U & BBA & 58 & Y & Y \\
\hline U of Alabama, Huntsville & BBA & 48 & Y & Y \\
\hline U of Central Florida & BBA & 45 & Y & Y \\
\hline U of Maryland, BC & BS & 18 & Y & Y \\
\hline U of New Mexico & BBA & 36 & Y & Y \\
\hline U of South Florida & BA/BS & 39 & Y & Y \\
\hline Western Carolina U & BSBA & 45 & Y & Y \\
\hline Average & & 38.3 & & \\
\hline
\end{tabular}

Table 10. Sample Universities Degrees \& Business Credits Required

\begin{tabular}{|l|c|c|c|c|}
\hline University & IS Credits & IS Credits & IS Credits & Programming \\
\hline Drexel & Required & Electives & Total & Credits Required \\
\hline Illinois State & 41 & 16 & 56 & 9 \\
\hline Kennesaw State & 22 & $20-23$ & $42-45$ & 9 \\
\hline Nebraska, Omaha & 34 & $9-15$ & $43-49$ & 9 \\
\hline NJ Institute of Tech & 33 & 12 & 45 & 4 \\
\hline North Florida & 42 & 15 & 57 & 6 \\
\hline Pace & 27 & 12 & 39 & 11 \\
\hline Robert Morris & 39 & 6 & 45 & 12 \\
\hline South Alabama & 27 & 12 & 39 & 3 \\
\hline Virginia Commonwealth & 50 & 9 & 59 & 6 \\
\hline Average & 30 & 9 & 39 & 6 \\
\hline
\end{tabular}

Table 11. ABET IS Requirements 2005 


\section{Issues in Information Systems}

Volume 13, Issue 1, pp. 151-159, 2012

\section{REQUIRED IS AND PROGRAMMING CREDITS}

The total required IS credits, elective IS credits, the total IS credits and the number of programming credits required are in Table 11 for 2005, Table 12 for 2008 and Table 13 for 2012. Because the BS degrees in IS generally do not require as many business credits they are able to take significantly more credits in IS.

\begin{tabular}{|l|c|c|c|c|}
\hline University & IS Credits & IS Credits & IS Credits & Programming \\
\hline & Required & Electives & Total & Credits Required \\
\hline Drexel & 41 & 16 & 56 & 9 \\
\hline Gannon & 45 & 6 & 51 & 18 \\
\hline Houston-Clear Lake & 18 & 0 & 18 & 6 \\
\hline Illinois State & 22 & $20-23$ & $42-45$ & 9 \\
\hline Jacksonville SU & 42 & 12 & 54 & 9 incl COBOL \\
\hline James Madison & 22 & 6 & 28 & Offered as elective \\
\hline Kennesaw State & 34 & $9-15$ & $43-49$ & 9 \\
\hline Lock Haven & 27 & 15 & 42 & 18 \\
\hline Maine & 54 & 15 & 69 & 9 \\
\hline Metropolitan S College & 21 & 6 & 27 & 3 \\
\hline Nebraska, Omaha & 33 & 12 & 45 & 4 \\
\hline NJ Institute of Tech & 42 & 15 & 57 & 6 \\
\hline North Florida & 27 & 12 & 39 & 11 \\
\hline Pace & 39 & 6 & 45 & 12 \\
\hline Quinnipiac & 29 & 6 & 35 & 6 \\
\hline Robert Morris & 27 & 12 & 39 & 3 \\
\hline U Scranton & 40 & 18 & 58 & 7 \\
\hline Slippery Rock & 31 & 3 & 34 & 9 \\
\hline South Alabama & 50 & 9 & 59 & 6 \\
\hline South Carolina & 40 & 3 & 43 & 12 \\
\hline Utah SU (CS not IS) & 21 & 6 & 27 & 10 \\
\hline Virginia Commonwealth & 30 & 9 & 39 & 6 \\
\hline Wright SU & 30 & 4 & 34 & 6 \\
\hline Average & $\mathbf{3 3 . 3}$ & $\mathbf{9 . 6 - 1 0 . 0}$ & $\mathbf{4 2 . 8 - 4 3 . 2}$ & $\mathbf{8 . 1}$ \\
\hline
\end{tabular}

Table 12. ABET IS Programs' Requirements 2008

\begin{tabular}{|l|l|c|c|c|}
\hline University & IS Credits & IS Credits & IS Credits & Programming \\
\hline & Required & Electives & Total & Credits Required \\
\hline Arkansas Tech U & 56 & 3 & 59 & 13 \\
\hline California SU, Chico & 40 & 3 & 43 & 6 \\
\hline California U of Penn & 46 & 3 & 49 & 12 \\
\hline Fitchburg SU & 33 & 9 & 42 & 9 \\
\hline Florida Memorial U & 45 & 9 & 54 & 6 \\
\hline Grand Valley SU & 39 & 3 & 42 & 3 \\
\hline Radford U & 36 & 0 & 36 & 6 \\
\hline Regis U & 48 & 0 & 48 & 3 \\
\hline Rowan U & 36 & 0 & 36 & 0 \\
\hline Southern Utah U & 42 & 16 & 54 & 6 \\
\hline U of Tampa & 34 & 3 & 37 & 0 \\
\hline U of Arkansas, Little Rock & 46 & 12 & 58 & 5 \\
\hline U of North Alabama & 30 & 6 & 36 & 6 \\
\hline Average & $\mathbf{4 0 . 8}$ & $\mathbf{5 . 2}$ & $\mathbf{4 6 . 0}$ & $\mathbf{6 . 2}$ \\
\hline
\end{tabular}

Table 13. ABET IS Requirements 2008-2012 


\section{Issues in Information Systems}

Volume 13, Issue 1, pp. 151-159, 2012

\section{CONCLUSION}

The trends noted in 2005 and 2008 are still valid in 2012. Thirty one of the 35 IS programs that are accredited by ABET are BS degrees. Most of these BS degrees are located in non-business colleges. There has been a slow but a steady growth of ABET accreditation of IS programs (35 programs in 10 years) but there were 3 new IS programs accredited in 2009 and only one new IS program accredited in 2010. ABET accreditation of IS programs has not yet become the standard IS accreditation. The MIS Rankings (2011), published by the US News \& World Report lists the top ranked MIS programs in the US. . It is notable that none of the 35 accredited IS programs listed in Table 5 are listed in these MIS rankings. For faculty interested in IS accreditation, the Topi (2011) paper gives a good summary of why accreditation should be important for information systems. The Kohun, DeLorenzo and Rodi (2011) paper presents an excellent explanation of the ABET "2001 Criteria for Computing Programs". After looking at the above data, it is recommended that if an IS program is not in a school/college of business, they should consider ABET accreditation. A selected number of chairs of IS programs in Colleges of Business were asked if it was worth all the work to become ABET accredited. All the chairs, except one, stated that they thought that ABET accreditation was worth all the work. One chair was not sure.

\section{REFERENCES}

1. AACSB (2012). Accreditation. Retrieved March 5, 2012, from http://www.aacsb.edu/accreditation/

2. ABET (2012a). Accredited Information Systems Programs, -ordered by name. Retrieved March 4, 2012 from http://main.abet.org/aps/Accreditedprogramsearch.aspx

3. ABET (2012b). Criteria for Accrediting Computing Programs, 2012-2013. Retrieved, March 4, 2012, from http://www.abet.org/computing-criteria-2012-2013/

4. Challa, C.D., Kasper, G.M., \& Redmond R. (2005). The Accreditation Process for IS Programs in Business Schools. Journal of Information Systems Education, 16 (2), 207-217.

5. Gorgone, J.T. (2004). Draft Information Systems Accreditation Criteria for 2006, the Special Interest Group on Computer Science Education (SIGCSE) Bulletin, 36(2), 15-17.

6. Hilton, T. S. \& Stone, M. (2003). MIS Program Accreditation: Comparing AACSB and ABET. IACI), Retrieved from http://isedj.org/isecon/2003/2211/ISECON.2003.Hilton.pdf

7. 7 .Hilton, T. S., Johnson, D. A., \& Kasper, G.M. (2004), ABET Accreditation of MIS Programs in AACSB Schools, In the Proceedings of Information Systems Education Conference (ISECON), 21, 1-16.

8. Hilton, T. S. \& Lo. B. W. (2007), IS Accreditation in AACSB Colleges via ABET, JAIS 8(1), Article 1 1-15

9. Jones, C. G. (2004). An Analysis of Programmatic Differences Between Dual ABET/AACSB and ABET-Only Accredited Information Systems Programs, IACIS, 2, 544-530.

10. 10. Kohun, F. G. \& Wood, D.F. (2003). The ABET CAC Accreditation Experience - Intent and Reality - the Information Systems Perspective, JISE, 1(43), 3-11.

11. Kohun, F. G. \& Wood, D.F. (2004). The ABET CAC Accreditation: Is Accreditation Right for Information Systems?, International Association for Computer Information Systems (IACIS), 2, 579-583.

12. Kohun, F.G. DeLorenzo, G.J. \& Roull, A. F. (2011) Are All Information Systems Created Equal - Does Accreditation Solidify Information As a Discipline?, IACIS, 12, 2, 264-272.

13. MacKinnon, R. J. \& Butler, S.E. (2005). How Do IS Programs Compare with ABET Accredited Programs? International Association for Computer Information Systems (IACIS), 6, 332-338.

14. MacKinnon, R. J. \& Han, HJ. (2008). An Analysis of IS Programs Accredited by ABET, Communications of the IIMA, 8,1,43-52.

15. MIS Rankings (2011), US News and World Report, Retrieved March 5, 2012 from

16. http://colleges.usnews.rankingsandreviews.com/best-colleges/rankings/business-management-informationsystem

17. Topi, Heikki (2011) IS Education: Accreditation of Degree Programs in Information Systems, ACM SIGCSE Bulletin, Volume 41, Issue 2, June 2009, 70-71. 